\title{
Povijest istraživanja umjetnosti baroka u 20. stoljeću
}

\section{Botica, Dubravka}

Source / Izvornik: Institucije povijesti umjetnosti : zbornik 4. kongresa hrvatskih povjesničara umjetnosti, 2019, 117 - 122

Conference paper / Rad u zborniku

Publication status / Verzija rada: Published version / Objavljena verzija rada (izdavačev PDF)

https://doi.org/10.31664/z4khpu.16

Permanent link / Trajna poveznica: https://urn.nsk.hr/urn:nbn:hr:254:106382

Rights / Prava: Attribution 4.0 International/Imenovanje 4.0 međunarodna

Download date / Datum preuzimanja: 2023-04-26

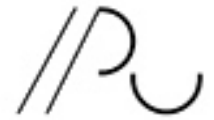

INSIIIUT ZA POVIIESTUMJETNOST
Repository / Repozitorij:

PODEST - Institute of Art History Repository

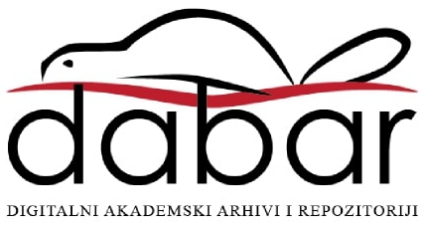




\section{Povijest istraživanja umjetnosti baroka u 20. stoljeću}

U povijesti umjetnosti, kao i u drugim humanističkim znanostima, odražava se „duh vremena”. Kroz metodologiju, izbor tema, a posebno interpretaciju povijesnoumjetničkih fenomena zrcale se suvremene tendencije, nedjeljive od društvenog, kulturnog, ali i političkog konteksta u kojemu su nastale. To je prepoznato u zadnjim desetljećima u našoj struci, iako u manjoj mjeri tematizirano negoli je to slučaj u (srednjo) europskoj povijesti umjetnosti. Iako historiografija povijesti umjetnosti u Hrvatskoj u 2o. stoljeću još nije napisana, posljednjih desetljeća zamjetan je trend istraživanja povijesti same struke, posebno njezinih početaka. ${ }^{1}$ Druga polovina stoljeća, odnosno razvoj znanstvenog diskursa povijesti umjetnosti u vrijeme sFRJ, tek je djelomice obrađen u sklopu drugih širih tema. ${ }^{2}$ Stoga je i prikaz istraživanja i interpretacije umjetnosti baroknog razdoblja u hrvatskoj povijesti umjetnosti moguće tek fragmentarno izložiti. Cilj je ovog rada u kratkim crtama naznačiti neke faze povijesti istraživanja barokne umjetnosti, a time i razvoja povijesti umjetnosti u Hrvatskoj u burnom dvadesetom stoljeću.

Počeci istraživanja barokne umjetnosti sežu u vrijeme kada je Hrvatska bila dio Austro-Ugarske Monarhije, a tada postavljene smjernice istraživanja uvelike će se nastaviti i u međuratnom razdoblju Kraljevine Jugoslavije. Razdoblje je obilježeno djelovanjem Artura Schneidera ${ }^{3}$ i Gjure Szabe, ${ }^{4}$ koje možemo smatrati i nastavljačima utemeljitelja struke, Ivana Kukuljevića Sakcinskog i Emilija Laszowskog. Tada se prvi put u hrvatskoj povijesti umjetnosti javlja pojam barok: uz Artura Schneidera, koji ga upotrebljava na predavanjima, Gjuro Szabo prvi se koristi terminom barok u našoj povijesti umjetnosti: "Crkva u Rozgi obična je barokna građevina." Szabo u svom djelovanju u Zemaljskom povjerenstvu za očuvanje umjetnih i historičkih spomenika u kraljevinama Hrvatskoj i Slavoniji obrađuje i spomenike i8. stoljeća ${ }^{6}$ te time postupno umanjuje snažan negativan stav prema umjetnosti baroknog razdoblja,

\section{Dubravka Botica}

Odsjek za povijest umjetnosti

Filozofski fakultet

Sveučilište u Zagrebu

dbotica@ffzg.hr

http://orcid.org/oooo-oooI-7698-ogo4

I Posebno valja istaknuti niz znanstvenih skupova Hruatski povjesničari umjetnosti održanih u organizaciji Društva povjesničara umjetnosti Hrvatske: Andela Horvat (I9II.-I985.), Znanstveni skup posvećen stotoj obljetnici rođenja, Zagreb, studeni 20II., radovi sa skupa objavljeni u: Peristil, 54 (20II.); Artur Schneider (I879. - I946.), studeni 20I3., radovi sa skupa objavljeni u: Artur Schneider: I879.-I946.: zbornik radova znanstveno-stručnog skupa Hrvatski povjesničari umjetnosti, (ur.) Ljerka Dulibić, Zagreb, Društvo povjesničara umjetnosti Hrvatske, 20I6.; Gjuro Szabo (I875.-I943.), listopad 20I5., radovi sa skupa objavljeni u Gjuro Szabo: 1875.- I943: zbornik radova znanstveno-stručnog skupa, (ur.) Marko Špikić, Zagreb, Društvo povjesničara umjetnosti Hrvatske, 2oI8. te Instituta za povijest umjetnosti i Hrvatskog instituta za povijest: Iso Kršnjavi-veliki utemeljitelj, studeni 20I2., radovi sa skupa objavljeni u Iso Kršnjavi-veliki utemeljitelj: zbornik radova znanstvenog skupa, (ur.) Ivana Mance, Zlatko Matijević, Zagreb, Institut za povijest umjetnosti, Hrvatski institut za povijest, 20I5.

2 Primjerice JASNA GALJER, Likovna kritika u Hrvatskoj I868.-I95I., Zagreb, Meandar media, 200o.; LJILJANA KOLEŠNIK, Likovne kritike i polemike 5o-ih godina u Hrvatskoj, u: Hrvatska likouna kritika 5oih-Croatian Art Criticism in the I950's. Izabrani tekstovi-Selected Essays, (ur. i prir.) Ljiljana Kolešnik, Zagreb, Društvo povjesničara umjetnosti Hrvatske, [200o.], 7-24; LJILJANA KOLEŠNIK, Između Istoka i Zapada. Hrvatska umjetnost i likovna kritika 5o-ih godina, Zagreb, Institut za povijest umjetnosti, 2006

3 O životu i djelovanju Artura Schneidera najnovije u: Artur Schneider: I879.-I946., Zbornik radova znanstveno-stručnog skupa Hrvatski povjesničari umjetnosti (bilj. I).

4 O životu i djelovanju Gjure Szabe opširnije u: TIHOMIL STAHULJAK, Gjuro Szabo-djelo jednog života, Zagreb, Društvo povjesničara umjetnosti Hrvatske, I995.

5 ANĐELA HORVAT, Barok u kontinentalnoj Hrvatskoj, u: ANĐELA HORVAT, RADMILA MATEJČIĆ, KRUNO PRIJATELJ, Barok u Hrvatskoj, Zagreb, I982., 9.

6 Posebno u Izvještajima o djelovanju povjerenstva: GJURO SZABO, Spomenici kotara Klanjec i Pregrada, u: Vjesnik Hrvatskog arheološkog društua, I9ı2., 207-239, GJURO SZABO, Spomenici kotara Krapina i Zlatar, u: Vjesnik Arheološkog muzeja u Zagrebu, I3/I (I9I4.), Io3-204, GJURO SZABO, Spomenici kotara Ivanec, u: Vjesnik Arheološkog muzeja u Zagrebu, I4/I (г9I9.), 22-97. 
koji je početkom 2o. stoljeća još uvelike prisutan u hrvatskoj povijesti umjetnosti, kao i u drugim zemljama srednje Europe. ${ }^{7}$ Anđela Horvat naglašava njegov izniman utjecaj kao pionira istraživanja baroka u Hrvatskoj, pogotovo kontinentalnog dijela, koji je kao konzervator, ali i publicističkim radom, pobudio interes javnosti za stanje i očuvanje spomenika. „Taj je solidni rad baza daljeg istraživanja spomenika na području sjeverne Hrvatske." ${ }^{\text {U }}$ metodologiji svog djelovanja i strukturi tekstova, koje odlikuje osebujan oštar stil pisanja, Szabo je uvelike postavio temelje znanstvenog proučavanja spomenika baroknog razdoblja-korištenje izvora i autopsije spomenika na licu mjesta. Boraveći u Beču na studiju germanistike od I892. do I896. godine, te u Nürnbergu, dolazi u doticaj s tada aktualnim idejama bečkih povjesničara umjetnosti, prije svega Aloisa Riegla. U svjetlu pristupa tumačenja umjetničkog htijenja, Kunstwollen, povijesnih razdoblja, ${ }^{9}$ odnosno objašnjavanja umjetničkih djela kao odraza unutarnjeg poticaja epohe, koja stvara jedinstven i neponovljiv stil u svim umjetničkim djelima, Szabo će formirati i svoj stav prema baroknoj umjetnosti. Taj pristup pitanjima stila i umjetničkom htijenju vremena progovara na više mjesta u Szabovim Izvještajima o djelovanju..., gdje interpretira barok kao kolektivno postignuće epohe: „Ranger je i u ovim slikarijama posve čovjek svoga vremena. Kako je barokno doba željelo veličajne prostorije za svoje velike ljude, tako ih je htjelo prirediti i svom najvećem gospodinu bogu", ${ }^{10} \mathrm{a}$ stil prepoznaje u svim umjetničkim djelima: „I najmanji komadić posuđa nosi biljeg svoga vremena; ponosni i samosvjesni barok nije htio ni u čem imitacije i slabašnoga kopiranja."11 Sukladno tomu, interes usmjerava i prema manjim spomenicima i zalaže se za njihovo očuvanje.

Djelovanje povjesničara umjetnosti i institucija u vrijeme Drugoga svjetskog rata odnosno Nezavisne Države Hrvatske još nije istraženo. No o interesu za baroknu umjetnost $\mathrm{u}$ tom razdoblju svjedoči zanimljiv dokumentarno-igrani film Barok u Hruatskoj, nastao u sklopu djelovanja Državnog slikopisnog zavoda Hrvatski slikopis, osnovana u siječnju I942. godine. ${ }^{12}$ Režiju, kameru i montažu potpisuje Oktavijan Miletić, scenarij povjesničar kulture Josip Horvat (prema memoarima grofa Oršića), a glazbu Boris Papandopulo. ${ }^{13}$ Tošo Dabac fotografski je bilježio stvaranje filma; u Arhivu Tošo Dabac pronađeno je čak I26 negativa, koji prate snimanje filma u dvorcima u Gornjoj Bistri i Brezovici, ${ }^{14}$ a iskorišteni su i za plakat filma (sl. I). Tako se ne samo sadržajem nego i visokom umjetničkom kvalitetom taj „kratki kulturni film”15 izdvaja iz serije kratkih filmova s ponajprije propagandnim ciljem nastalih u Hrvatskom slikopisu, i nastoji umjetnost tog razdoblja približiti široj publici. Film je s velikim uspjehom prikazan na filmskom festivalu u Veneciji I942. godine, a posebno zanimanje izazvao je plakat za film. ${ }^{16}$

Temeljita promjena okolnosti djelovanja, društvenog uređenja, a posebno vladajuće ideologije, koja je snažno utjecala na poimanje i bavljenje umjetnošću, nastupa u Socijalističkoj Federativnoj Republici Jugoslaviji. U četiri i pol desetljeća socijalističkoga društvenog uređenja kao tek grubu skicu
7 Kultermann tako kao bitnu odrednicu razvoja povijesti umjetnosti u vrijeme utemeljitelja, Gründerzeit, navodi „ponovno otkrivanje baroka”, odnosno uklanjanje negativnog stava i pristupa toj stilskoj epohi, koji je baštinilo od romantičara I9. stoljeća. Ključnu ulogu pri tom su imali Cornelius Gurlitt, Alois Riegel i Georg Dehio. Usp. UDO KULTERMANN, Geschichte der Kunstgeschichte, München, Prestel Verlag, I996., I22 i d.

8 ANĐELA HORVAT, Biografija, u: GJURO sZABO, Kroz Hrvatsko zagorje, Zagreb, I974., 22.

9 U djelima Riegla Stilfragen (Berlin, I893.), a posebno Die spätrömische Kunstindustrie nach den Funden in Österreich-Ungarn (Beč, Igor.) kao i Die Entstehung der Barockkunst in Rom: Vorlesungen aus I9OI-I902, (ur.) Arthur Burda, Max Dvořák (Beč, I9o8.), UDO KULTERMANN (bilj. 7), I53-I56.

Io GJURO SZABO (bilj. 6, I9I9.), 34 .

II GJURO SZABO (bilj. 6, I9I4.), I59.

I2 Opširnije o osnivanju i djelovanju slikopisnog zavoda u: DANIEL RAFAELIĆ, Kinematografija u NDH, Zagreb, Naklada Ljevak, 20I3., 74 i d.

I3 IVA PROSOLI, Tošo Dabac i film, u: Hrvatskifilmski ljetopis 89 (20I7.), 87. Zahvaljujem kolegici Prosoli, koja mi je ustupila rad dok je bio u postupku objavljivanja. I4 IVA PROSOLI (bilj. I3), 87 .

I5 DANIEL RAFAELIĆ (bilj. I2), 82, navodi da su osnovni zadaci u Odjelu za proizvodnju unutar slikopisnog zavoda bili proizvodnja filmskih tjednika (žurnala), kratkih kulturnih filmova te filmova potpune dužine. I6 DANIEL RAFAELIĆ (bilj. I2), IO2. 
društvenog konteksta možemo naznačiti razvoj od uspostave stroge kontrole i snažne ideologizacije svih sfera na prijelazu u pedesete pa do slabljenja zadanog ideološkog okvira i otvaranja brojnim novim temama u zadnjim desetljećima. U ključnom razdoblju kraja I940-ih i tijekom I950-ih definira se kulturna politika i stav prema umjetnosti i njezinoj ulozi u društvu, a i ulozi i zadacima humanističkih, posebno povijesnih znanosti, tako i povijesti umjetnosti. Stavovi i kriteriji postavljeni I950-ih zadržat će se sve do kraja SFRJ, iako tijekom vremena manje obvezujući i prisutni. Utjecaj tako snažna ideološkog okvira na znanstveni diskurs i izbor tema još nije dostatno razmatran, kao što je to u nekim zemljama istočnog bloka tematizirano. ${ }^{17}$ Umjetnost baroknog razdoblja nije bila u središtu povijesnoumjetničkih istraživanja u socijalističkoj epohi. Pojednostavnjeno se može ustanoviti da je njihovo težište bilo s jedne strane na istraživanju umjetnosti srednjeg vijeka u jadranskom priobalnom području i zaleđu, pri čemu su pitanja podrijetla i određivanja „nacionalne" umjetnosti, odnosno definiranja uloge domaćih majstora, bili u prvome planu. ${ }^{18}$ Drugo je težište suvremena umjetnost 2o. stoljeća.

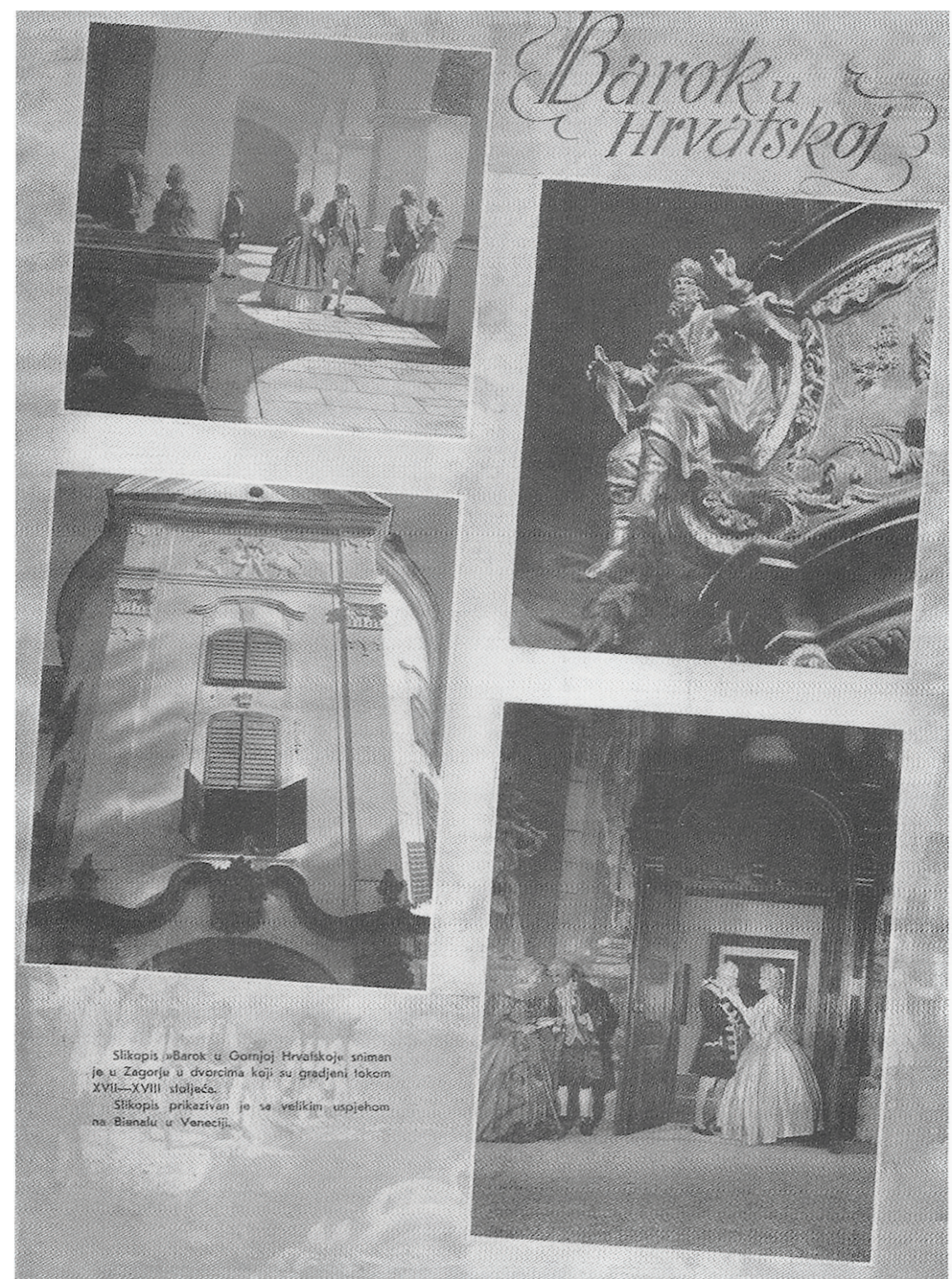

I7 Npr. KRISTA KODRES, Scientific Baroque-for everyone. Constructing and conveying an art epoch during the Stalinist period in the Soviet Union and in Soviet Estonia, u: Journal of Art Historiography, I5 (20I6.), I-25, https://arthistoriography.files.wordpress.com/2oI6/II/kodres.pdf (posjećeno 5. ožujka 20I7.).

I8 Npr. u brojnim djelima CVITE FiskovićA, Dokumenti o radu naših graditelja i klesara XV-XVI stoljeća u Dubrovniku, Split, I947., CVITO FISKOVIĆ, Prvi poznati dubrovački graditelji, Dubrovnik, I955. Važan je doprinos istraživanjima „domaće sredine” i LJUBE KARAMANA, O djelovanju domaće sredine u umjetnosti hrvatskih krajeva, Zagreb, I963. Taj pristup „nacionalne konstante” (nationale Konstante) nastavlja se u međuratnom razdoblju, a traje i nakon Drugoga svjetskog rata, posebno u povijesti umjetnosti tzv. „malih" naroda, usp. ADAM S. LABUDA, Einleitende Bemerkungen zur Rolle des nationalen Gedankens in der Kunstgeschichtsschreibung, u: Die Kunsthistoriographien in Ostmitteleuropa und der nationale Diskurs, (ur.) Robert Born, Alena Janatková, Adam S. Labuda, Berlin, 2004., 40.

\section{Slika I}

Plakat za film Barok u Hrvatskoj

fotografija preuzeta iz: DANIEL RAFAELIĆ,

Kinematografija u NDH, Zagreb, 20I3. 

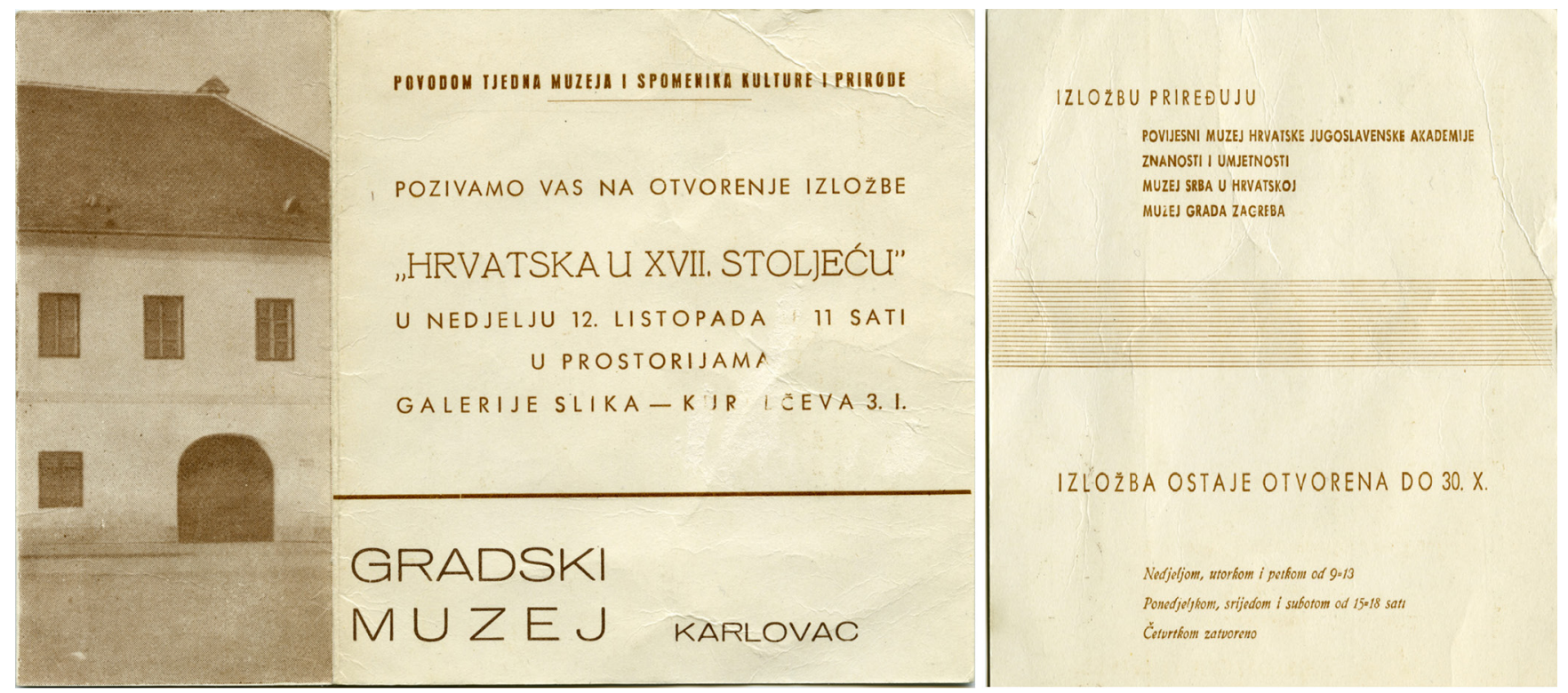

Slika 2

Plakat za izložbu Hrvatska u XVII.

stoljeću, Gradski muzej Karlovac,

Arhiv Muzeja grada Zagreba

Zanimljiva je stoga izložba koja se I950-ih bavi I7. stoljećem, i gotovo je izoliran fenomen, a ujedno se (unatoč?) svojoj tematici ne obraća užoj stručnoj javnosti, nego je osmišljena da dopre do što većeg kruga. Istovremeno odražava nov pristup u postavljanju i organizaciji te funkciji samih izložbi, koji je obilježio to desetljeće. ${ }^{19}$ Izložbu Hrvatska u XVII. stoljeću organizirali su Povijesni muzej Hrvatske, Muzej Srba u Hrvatskoj i Muzej grada Zagreba, a bila je postavljena od 9. do I7. lipnja I958. u zagrebačkom Muzeju grada. ${ }^{20}$ Nakon toga bila je postavljena u Sisku, gdje je bila popratna izložba uz VI. slet bratstva i jedinstva, te u Karlovcu i Samoboru ${ }^{21}$ (sl. 2). Nažalost, popratni materijal uz izložbu nije sačuvan u arhivi muzeja, no iz novinskih tekstova koji su pratili izložbu, kao i iz fotografija, ${ }^{22}$ mogu se analizirati najvažnije značajke postava čiji su autori arhitekt Zvonimir Marohnić i akademski slikar Boris Dogan. U svakom muzeju gdje je izložba gostovala postav je nadopunjavan eksponatima iz lokalnih zbirki, a bila su organizirana i popratna događanja. ${ }^{23}$ Osim u staklenim vitrinama, izlošci su bili postavljeni na panoima ovješenima na čeličnu konstrukciju. Opisi i fotografije postava ukazuju na usvajanje tada dominantne nove estetike, koja će se na izložbama i u muzejima primjenjivati za postave i izlaganje suvremenih tema, osobito industrijskog dizajna, ali rjeđe u izložbama povijesne tematike. Sama organizacija izložbe pak svjedoči o primjeni smjernica koje proizlaze iz tada dominantne ideje približavanja umjetnosti „običnom” čovjeku, koje je najpreciznije formulirao Radovan Ivančević u knjizi Likouna kultura „običnog” čovjeka iz Ig6r. godine. ${ }^{24}$ Naglašava važnost popratnih
I9 Opširnije vidi DUBRAVKA BotiCA, Baroque in Croatia. Presentation of baroque culture in Croatia in the socialist period, u: Journal of Art Historiography, I5 (20I6.), https://arthistoriography.files.wordpress. com/20I6/II/botica.pdf (posjećeno 5. ožujka 20I7.).

20 http://www.mgz.hr/hr/izlozbe/hrvatska-u-I7-stoljecu,434.html (posjećeno 5. ožujka 20I7.).

2I Nakon Siska izložba je gostovala na nekim gradilištima Autoputa bratstva i jedinstva, a kasnije je prenesena u Karlovac i Samobor. Bila je postavljena i na Kongresu historičara Jugoslavije u Zagrebu iste godine.

22 U. V., Izložba „Hrvatska u XVII. stoljeću”, u: Narodni list, 24. lipnja r958., 4.

23 Fotografije uz tekst o postavu u Gradskom muzeju u Sisku, BRANKO SUČEVIĆ, Pokretna izložba „Hrvatska u XVII. stoljeću”, u: Vijesti Društva muzejsko-konzervatorskih radnika NR Hrvatske 7, 4 (I958.), 96-98.

24 RADOVAN IVANČEVIĆ, Likovna kultura "običnog” čovjeka, Zagreb, Radničko sveučilište „Moša Pijade”, I96ı. 
sadržaja uz izložbe, koji će publici koja nema naviku posjeta galerijama i muzejima približiti samu tematiku, ${ }^{25}$ kako je organizirano i uz spomenutu izložbu.

$\mathrm{U}$ istraživanju umjetnosti i kulture baroknog razdoblja $\mathrm{u}$ Hrvatskoj mogu se povući paralele s istraživanjima barokne umjetnosti u drugim socijalističkim zemljama. Razdoblje baroka kao predmet istraživanja posebno je zanimljivo u ovom kontekstu prikaza razvoja povijesnoumjetničkog diskursa, jer je kao razdoblje u kojem, pojednostavnjeno rečeno, dominiraju crkva i plemstvo, u potpunoj suprotnosti s vladajućom ideologijom socijalizma odnosno komunizma. To je rezultiralo upravo naglašenim izostavljanjem razmatranja kulturnog i društvenog konteksta baroknog razdoblja, najjasnije vidljivo u izostavljanju istraživanja naručitelja umjetničkih djela i usmjeravanju na istraživanje čiste forme i stila. Kako je istaknuto na simpoziju Asymmetrische Kunstgeschichte održanu na Humboldt Universität u Berlinu 20I4. godine, to se provlači kao zajednička karakteristika odnosa prema umjetnosti baroknog razdoblja u različitim sredinama zemalja istočnog bloka. ${ }^{26}$ Te tendencije očituju se i u djelima vodećih povjesničara umjetnosti koji su uvelike oblikovali struku u Hrvatskoj, ako izdvojimo monografiju Vere Horvat Pintarić o kiparu Francescu Robbi s naglaskom na ekspresiji djela i analizi forme (I96r.), ${ }^{27}$ ili knjigu Vladimira Markovića o baroknim feudalnim dvorcima u Hrvatskom zagorju, u kojoj je naglasak na tipologiji tlocrtnih rješenja. ${ }^{28}$

Promjenu u pristupu i metodologiji istraživanja barokne umjetnosti, kao i u temi i korpusu koji obrađuje, znači opus Anđele Horvat, posebno knjiga Između gotike $i$ baroka iz I975. godine. ${ }^{29}$ Manje pod utjecajem teoretskog diskursa, koji je nužno bio ideološki opterećen, dolazeći iz konzervatorske djelatnosti Horvatova je usmjerena prema kontinentalnoj Hrvatskoj i umjetničkim razdobljima koja su ostavila najviše spomenika, prije svega baroknom razdoblju. Otvara niz novih tema-posebno je važno njezino istraživanje cjelovitog konteksta nastanka umjetničkog djela, a time i uloge naručitelja. ${ }^{30} \mathrm{U}$ metodološkim pitanjima, u sredini koja paradigmu stilske povijesti umjetnosti nikada nije kritički razmotrila, otvorila je put sagledavanju pluralističke slike stilova, koja je nužna u istraživanju srednjoeuropskog korpusa umjetničke baštine ${ }^{31} \mathrm{Uz}$ to, njezina sinteza u tekstu Barok u kontinentalnoj Hrvatskoj u monumentalnoj monografiji Barok u Hrvatskoj iz I982. godine ${ }^{32}$ dala je ključni zamah istraživanjima barokne umjetnosti kod nas. I980-ih polako se počinje razvijati snažniji interes za umjetnost baroknog razdoblja, čemu je pridonijela i nova kulturna politika u vodećim muzejima, ali i nove političke okolnosti nakon Titove smrti ig8o. godine. Razdoblje I980-ih i ı99o-ih obilježeno je velikim izložbenim projektima i prikazima umjetničke baštine pavlinskog reda, ${ }^{33}$ isusovačkog reda $^{34}$ i baštine na području Zagrebačke nadbiskupije. ${ }^{35}$ Tim važnim izložbama i popratnim katalozima nastaje nova slika umjetnosti baroknog razdoblja u stručnoj, ali i široj javnosti, dakle možemo govoriti o svojevrsnom "kanoniziranju baroka” u Hrvatskoj, kako je taj proces nazvan u studiji o istraživanju
25 RADOVAN IVANČEVIĆ (bilj. 24), $5^{\mathrm{I}^{-}} 5^{2}$.

26 EVA PLUHAŘovÁ-GRIGIENÉ, Asymmetrische Kunstgeschichte?, Humboldt-Universität zu Berlin, 24.-25.04.20I4 [review], u: H-ArtHist, or July 20I4, http://arthist.net/reviews/8IIg (posjećeno 5. ožujka 2OI7.).

27 VERA HORVAT PINTARIĆ, Francesco Robba, Zagreb, Društvo historičara umjetnosti NRH, I96I.

28 VLADIMIR MARKOVIĆ, Barokni dvorci Hrvatskog zagorja, Zagreb, Kajkavsko spravišče, I975., drugo izdanje Zagreb, Nacionalna i sveučilišna biblioteka, I995.

29 ANĐELA HORVAT, Između gotike i baroka. Umjetnost kontinentalnog dijela Hrvatske od oko I50o. do oko I7oo., Zagreb, Društvo povjesničara umjetnosti Hrvatske, I975.

3o Posebno u nizu prikaza umjetničke baštine sjeverozapadne Hrvatske, ANĐELA HORVAT, Pregled spomenika s područja općine Klanjec, u: Kaj, XI [i. e. XII], 3 (I979.), I5-70, ANĐELA HORVAT, Pregled spomenika kulture područja općine Zabok, u: Kaj, XII [i. e. XIII], I (I980.), 67-I25, ANĐELA HORVAT, O spomenicima kulture općine Krapina, u: Kaj, XIII [i. e. XV], I (I982.), 87-I42, ANĐELA HORVAT, Pregled spomenika kulture općine Pregrada, u: Kaj, XVIII, 2-3 (I985.), I67-208.

3 I Utvrđivanjem paralelnih stilskih pojava Anđela Horvat uvela je pristup istraživanja oslobođen od paradigme stilskih razdoblja i otvorila pristup proučavanju znatnog dijela korpusa koji se ne „uklapa” u idealnu sliku nizanja stilova. DUBRAVKA BOTICA, Današnje čitanje teza Anđele Horvat. Arhitektura I7. stoljeća u kontinentalnoj Hrvatskoj između gotike $i$ baroka, u: Peristil 54 (20II.), I43-I50.

32 ANĐELA HORVAT (bilj. 5).

33 Kultura pavlina u Hrvatskoj I244-I786: slikarstvo, kiparstvo, arhitektura, umjetnički obrt, knjižeunost, glazba, prosvjeta, ljekarstvo, gospodarstvo, (ur.) Đurđica Cvitanović, Vladimir Maleković, Jadranka Petričević, Zagreb, Muzej za umjetnost i obrt, I989.

34 Isusovačka baština u Hrvata, (ur.) Biserka Rauter Plančić, Zagreb, Muzejsko galerijski centar, I993.

35 Sveti trag: devetsto godina umjetnosti Zagrebačke nadbiskupije, Io94.-I994., (ur.) Tugomir Lukšić, Ivanka Reberski, Zagreb, Muzej Mimara, I994. 
austrijskog baroka. ${ }^{36}$ Važno je naglasiti da su se te izložbe, iako tematski široko koncipirane, bavile sakralnom umjetnošću, dok je profana umjetnost, a posebno kultura barokne svakodnevice, bila gotovo potpuno zanemarena. Osim kultne studije Josipa Matasovića O galantnom stoljeću iz I92I. ${ }^{37}$ i izložbe i kataloga Od suagdana do blagdana iz I993.. ${ }^{38}$ koja je organizirana $u$ godini srednjoeuropskog baroka, tema je ostala izvan fokusa istraživanja. Rijetku iznimku predstavlja izložba Život u palači od I764. do 2004., održana u Hrvatskom povijesnom muzeju 2004. godine. ${ }^{39}$

Ova skica razvoja istraživanja i interpretiranja barokne umjetnosti u hrvatskoj povijesti umjetnosti naglo se prekida u posljednjem desetljeću 20. stoljeća. Ratna razaranja I99ı.-I995. i poslijeratna obnova u prvi plan su razumljivo stavili teme očuvanja i obnove baštine. Početak 2I. stoljeća donio je zanimljive nove impulse: otvorene su brojne nove teme, za razliku od ranije zatvorenosti u državne, pa čak i regionalne okvire, sama struka znatno je otvorenija. To se očituje u naglašavanju istraživanja hrvatske umjetnosti u europskome kontekstu i povezivanja sa stranim umjetničkim krugovima. Ta tendencija zasigurno će se nastaviti i dalje, a vidjet ćemo koje će se nove teme razvijati u sada izrazito heterogenoj slici istraživanja baroka u hrvatskoj povijesti umjetnosti.

\section{(ㅇ) (1)}

Povijest istraživanja umjetnosti baroka u 2o. stoljeću / Dubravka Botica / CC BY / 4.O

DOI: https://doi.org/ıo.31664/z4khpu.I6
36 Velikim izložbenim projektima u razdoblju između dva rata, a posebno otvaranjem Muzeja baroka u dvorcu Donji Belvedere I923. „Durch diese Musealisierung des Barock kam es auch zu dessen Kanonisierung", GEORG LECHNER, Was ist Barock, was barock? Ein Stil und seine Entdeckung, u: Barock since I63o, (ur.) Agnes Husslein-Arco, Georg Lechner, Alexander Klee, Beč, Österreichische Galerie Belvedere, 20I3., I7.

37 JOSIP MATASOVIĆ, Iz galantnog stoljeća-kulturnohistorijski fragmenti, 2. izdanje, (ur.) Teodora Shek Brnardić, Zagreb, 2008.

38 Od svagdana do blagdana: barok u Hrvatskoj, (ur.) Vladimir Maleković, Zagreb, Muzej za umjetnost i obrt, I993.

39 MARINA BREGOVAC PISK, Život u palači od I764. do 2004. godine, Zagreb, Hrvatski povijesni muzej, 2004. 